\title{
Influence of milk source and ripening time on free amino acid profile of Picante cheese
}

\author{
A. Cristina Freitas, ${ }^{*}$ J. María Fresno, ${ }^{\dagger}$ \\ Bernardo Prieto, ${ }^{\dagger}$ Inmaculada Franco, ${ }^{\dagger}$ \\ F. Xavier Malcata*§ and Javier Carballo ${ }^{\ddagger}$
}

The evolution of concentration of free amino acids in Picante cheese throughout ripening was studied for several volumetric ratios of ewe's and goat's milks. The concentrations of all free amino acids, except asparagine, $\gamma$-aminobutyric acid, and cysteine, generally increased as ripening time elapsed. Analyses of variance have indicated that ripening time and, to a lesser extent, milk composition have significant effects on the overall concentration of free amino acids. The major free amino acids present in the various cheeses along the ripening period were valine, leucine, and phenylalanine; these three amino acids accounted for 50, 49, 57, 46 and $42 \%$ of total free amino acids at 0 days and $42,42,43,39$ and $36 \%$ of total free amino acids at 180 days for cheeses manufactured with 0,25, 50,75 and $100 \%$ goat's milk, respectively. Significant differences could be detected in terms of amino acid profile when the relative proportions of ewe's and goat's milks were altered (eg valine changed from $251.79 \pm 0.99$ to $352.20 \pm 16.49 \mathrm{mg} / 100 \mathrm{~g}$ of dry matter, leucine from $181.48 \pm 1.77$ to $226.00 \pm 11.60 \mathrm{mg} / 100 \mathrm{~g}$ of dry matter, and phenylalanine from $120.39 \pm 1.44$ to $155.36 \pm 8.39 \mathrm{mg} / 100 \mathrm{~g}$ of dry matter in 140-day ripened cheeses when plain ewe's milk was replaced by plain goat's milk). The correlation coefficients between the concentrations of valine, isoleucine, leucine and phenylalanine, on the one hand, and ripening time, on the other, were greater than 0.93 .

\section{INTRODUCTION}

Picante is a Portuguese traditional cheese produced on the farm level only from blends of raw ewe's and goat's milks, and possesses a few distinctive characteristics: it is hard, salty and spicy. Picante cheesemaking milk is coagulated with animal liquid rennet

\footnotetext{
* Escola Superior de Biotecnologia, Universidade Católica Portuguesa, Rua Dr António Bernardino de Almeida, P-4200 Porto, Portugal, 'Departamento de Higiene y Tecnología de los Alimentos, Universidad de Léon, 24071 León, Spain and ${ }^{\ddagger}$ Area de Tecnología de los Alimentos, Facultad de Ciencias de Orense, Universidad de Vigo, 32004 Orense, Spain. "To whom correspondence should be addressed.
}

extracted from calf's stomach without addition of a starter culture; fresh cheeses are rubbed with dry salt after manufacture and ripened via appropriate piling up on straw and sand in maturation rooms. Studies on this cheese, which must be ripened for at least 120 days to meet the legal specification, are relatively scarce (Freitas and Malcata, 1996; Freitas et al., 1995, 1996, 1997), and most of those available are virtually outdated (eg Cruz et al., 1945).

Proteolysis is one of the most important phenomena that takes place during cheese ripening, and studies pertaining to the evolution of the free amino acid profile in several cheeses during ripening have been published (Marcos and Mora, 1982; Polo et al., 1985; Ramos et al., 1987; González de Llano et al., 
1991; Fresno et al., 1993; Barcina et al., 1995). Primary proteolysis in cheese may be defined as the set of those chemical changes in $\beta$ - and $\alpha_{\mathrm{s}}$-caseins (and large polypeptides derived thereof) that are detected by polyacrylamide gel electrophoresis (Rank et al., 1985); products of secondary proteolysis in cheese encompass small peptides and free amino acids that are soluble in the aqueous phase of cheese and are thus recovered in the water-soluble fraction. In Picante cheese a moderate ripening extension index is often observed, namely, $25-29 \%$ of total nitrogen by 6 months (Freitas et al., 1997), which, according to Furtado and Partridge (1988), is an indication of moderate rennet activity. Peptides and free amino acids released via (cellular or cell-free) proteolytic enzymes have been implicated with flavour intensity (McGugan et al., 1979) and can be used to monitor cheese ageing (Aston and Dulley, 1982; González de Llano et al., 1991). The non-protein nitrogen (NPN) changes throughout ripening time in Picante cheese are characterized by slight increases in early stages of ripening and large increases in late stages of ripening, with maximum NPN values of 87 and $92 \%$ of water soluble nitrogen (WSN) in Picante cheeses manufactured with plain ewe's and plain goat's milk, respectively, by 180 days of ripening. These values indicate that fully ripened Picante cheese exhibits a high ripening depth index, which in turn suggests an important role for small peptides and free amino acids in Picante cheese characteristics.

This manuscript reports results of a research effort aimed at monitoring the concentrations of free amino acids throughout ripening and ascertaining the effect of different ratios of addition of ewe's to goat's milks therein; this study is warranted because the traditional protocol of Picante cheese manufacture allows for the use of virtually any proportion of ewe's and goat's milks (and the legal Portuguese regulation encompassing this AOP cheese is not yet explicit on such proportion either), and so it is anticipated that effective standardization of this cheese will require a more defined protocol of manufacture leading to a more defined set of final specifications. Furthermore, Picante is one of the Portuguese cheeses manufactured from raw milk that is ripened for the longest period, so its composition in free amino acids is particularly important due to their organoleptic role.

\section{MATERIAL AND METHODS}

\section{Cheesemaking protocol, experimental design, and cheese sampling}

In order to study the effects of ripening time and volumetric ratio of milks, five batches of mixtures of raw ewe's and goat's milk, with the compositions 0/100 (goat's/ewe's), 25/75, 50/50, 75/25 and 100/0\% $(\mathrm{v} / \mathrm{v})$ were prepared; these batches will be denoted hereafter as $0 \mathrm{C}, 25 \mathrm{C}, 50 \mathrm{C}, 75 \mathrm{C}$ and $100 \mathrm{C}$, respectively. For each aforementioned batch, $90 \mathrm{l}$ of milk were used to manufacture 20 cheeses according to traditional procedures described in detail by Freitas et al. (1996), ie milk was coagulated with liquid rennet extracted from calf's stomach (Fabre, Monza, Italy) without addition of any starter culture. Fresh cheeses were rubbed with dry salt after manufacture, and cheeses were ripened for 180 days via appropriate piling up on straw and sand in maturation rooms.

Ten cheeses (two cheeses from each batch) taken randomly were sent under refrigerated conditions to our laboratory at $0,9,25,40,55,83,110,140$ and 180 days of ripening to be analyzed. The resulting experimental layout was thus a $5 \times 9$ full factorial design replicated twice.

\section{CHEESE ANALYSIS}

\section{Chemicals}

Potassium hydroxide, sodium acetate trihydrate, sodium bicarbonate, acetic acid, phosphoric acid, ethanol, disodium hydrogen phosphate, perchloric acid and acetronitrile (liquid chromatography grade) were obtained from Pancreac (Barcelona, Spain). Triethylamine (liquid chromatography grade), phenylisothiocyanate solution (PITC) (protein sequencing grade) and amino acid standards (liquid chromatography grade) were purchased from Sigma (St Louis, MO, USA).

\section{Equipment}

A liquid chromatography system consisting of a ternary pump model SP-8800 and a column heater model SP-8792 from Spectra-Physics (San José, CA, USA), an injector model 7125 from Rheodyne (Cotati, CA, USA), a UV-spectrophotometer model 730 S LC from Kontron Uvikon (Middlesex, UK) and an integrator model SP-4290 from Spectra-Physics were used to perform the free amino acid analysis. Elution was performed in a Brownlee ${ }^{\mathrm{TM}} \mathrm{C}_{18}$ reversedphase column $(25 \times 0.46 \mathrm{~cm})$ from Applied Biosystems (Foster City, CA, USA).

\section{Sample preparation}

Samples of $10 \mathrm{~g}$ of cheese were dissolved in $40 \mathrm{ml}$ of $0.6 \mathrm{~N}$ perchloric acid and homogenized in a Sorvall Omni-mixer (Waterbury, CT, USA) for $2 \mathrm{~min}$. The mixture was centrifuged at $1790 \mathrm{~g}$ for $5 \mathrm{~min}$ in a Heraeus Christ centrifuge (Osterode, Germany), the supernatant was filtered through No. 54 filter paper (Whatman, Maidstone, UK) and its $\mathrm{pH}$ was adjusted to 6.0 with $1 \mathrm{~N}$ potassium hydroxide. The filtrate was then placed in an ice bath for $c a .20 \mathrm{~min}$, filtered again with No. 54 filter paper and concentrated at $40^{\circ} \mathrm{C}$ in a rotavapor R-Büchi (Switzerland). The dry extract was dissolved in $20 \mathrm{ml}$ of $0.5 \mathrm{M}$ sodium 
bicarbonate ( $\mathrm{pH} 8.5)$. The mixture was finally passed through Millex-Gs $0.45 \mu \mathrm{m}$ filter (Millipore, Molsheim, France) and frozen for later analysis by HPLC. Derivatization of amino acids with PITC was performed according to Alonso et al. (1994); depending on the expected total free amino acid concentration of the sample, different volumes $(50-300 \mu l)$ of extract were evaporated to driness at $37^{\circ} \mathrm{C}$ under liquid nitrogen; the residue, corresponding to the derivatized dried samples, was dissolved in 400-1200 $\mu \mathrm{l}$ of diluent (prepared by dissolving $710 \mathrm{mg}$ of disodium hydrogen phosphate in 11 of water-acetronitrile at the volumetric ratio of $19: 1$ and by adjusting $\mathrm{pH}$ to 7.40 with phosphoric acid).

\section{Chromatographic analysis}

The Pico-Tag ${ }^{\mathrm{TM}}$ method for sample preparation and analysis was used according to Alonso et al. (1994) with some modifications: the gradient conditions are depicted in Table 1, the column temperature was $50^{\circ} \mathrm{C}$ and detection was by absorbance at $254 \mathrm{~nm}$. The amounts of free amino acids in the various cheese samples were calculated using peak area values from two analytical replications and converted to concentrations using calibration curves previously obtained from amino acid standards (Sigma) dissolved in $0.5 \mathrm{M}$ sodium bicarbonate.

\section{Statistical analysis}

The effect of ripening time and volumetric ratio of goat's in cheesemaking milk on the concentration of every free amino acid was assessed using the ANOVA methodology; for each significant effect, the corresponding critical difference was assessed by Scheffé's $F$ multiple comparison test at the 5\% significance level. Linear relationships between the concentration of the major free amino acids and ripening time were also statistically evaluated. All statistical analyses were carried out with the StatView $^{\text {TM }}$ software v. 4.01 (Abacus Concepts, Berkeley, CA, USA).

Table 1 Solvent gradients used in the HPLC method

\begin{tabular}{cccc}
\hline $\begin{array}{l}\text { Run time } \\
(\mathrm{min})\end{array}$ & $\begin{array}{c}\text { Solvent A } \\
(\%)\end{array}$ & $\begin{array}{c}\text { Solvent B } \\
(\%)\end{array}$ & $\begin{array}{c}\text { Flow rate } \\
(\mathrm{ml} / \mathrm{min})\end{array}$ \\
\hline 0.0 & 100 & 0 & 0.90 \\
5.0 & 100 & 0 & 0.80 \\
20.0 & 78 & 22 & 0.75 \\
40.0 & 54 & 46 & 0.80 \\
42.0 & 0 & 100 & 1.00 \\
43.0 & 0 & 100 & 1.00 \\
44.0 & 100 & 0 & 1.00 \\
46.0 & 100 & 0 & 1.50 \\
47.5 & 100 & 0 & 0.90 \\
\hline
\end{tabular}

Solvent A: $19 \mathrm{~g}$ sodium acetate trihydrate in 11 water. To this solution, $500 \mu \mathrm{l}$ of triethylamine was added; the $\mathrm{pH}$ was then adjusted to 6.40 with glacial acetic acid; $940 \mathrm{ml}$ of this solution were then mixed with $60 \mathrm{ml}$ of pure acetonitrile. Solvent B: $600 \mathrm{ml}$ acetonitrile plus $400 \mathrm{ml}$ of water.

\section{RESULTS AND DISCUSSION}

The evolution of the total concentration of free amino acids (FAA) in the various experimental cheeses is depicted in Figure 1; the content of total FAA increased continuously from ca. $30-54 \mathrm{mg} /$ $100 \mathrm{~g}_{\mathrm{DM}}$ (where DM denotes dry matter) at 0 days to $1330-1942 \mathrm{mg} / 100 \mathrm{~g}_{\mathrm{DM}}$ by 180 days. The release of total FAA accelerated between 3 and 6 months of ripening (see Figure 1), and this behaviour is coincident with acceleration of protein breakdown (Freitas et al., 1997). According to Furtado and Partridge (1988), high levels of NPN are an indication of a strong starter peptidase activity, whereas Schmidt and Lenoir (1972) and Wallace and Harmon (1970) reported that enterococci possess a high proteolytic activity, especially Enterococcus faecalis ssp. faecalis; Freitas $e t a l$. (1996) reported that enterococci and lactobacilli were the predominant groups of lactic acid bacteria present throughout ripening of Picante cheese and that Enterococcus faecium was the most abundant species of the genus Enterococcus (immediately followed by Enterococcus faecalis), so their metabolic action may play an important role in the release of FAA.

The differences in terms of total FAA content between the various batches of cheese became higher as ripening time elapsed (see Figure I); the $75 \mathrm{C}$ cheeses presented, by 180 days, the highest value of total FAA content, whereas the total FAA content in the $100 \mathrm{C}$ cheeses decreased slightly between 140 and 180 days. It is noteworthy that both the $75 \mathrm{C}$ and $100 \mathrm{C}$ cheeses obtained the highest scores in terms of texture and flavour (Freitas et al., 1997). The ANOVA indicated that the ratio of addition of goat's to ewe's milk and, to a greater extent, the ripening time have significant effects on the total FAA content. The effect of milk composition likely arises from two factors: (i) goat's milk contains higher total quantities of amino acid residues in milk proteins than ewe's milk (Stojslavljevic et al., 1971); and (ii) a higher proportion of goat's milk leads to more extensive proteolytic breakdown (Freitas et al., 1997).

The results obtained from the assays for the various free amino acids throughout the ripening period and for cheeses manufactured with different volumetric ratios of ewe's and goat's milks are displayed in Tables 2-4. From inspection of these tables, it can be observed that the concentration of every free amino acid generally increases throughout the ripening period except for asparagine, $\gamma$-aminobutyric acid and cysteine; the contents of these free amino acids decrease in all experimental cheeses at least between 140 and 180 days. Some variability in terms of the content of several free amino acids was observed in a few sampling points, eg for the $\mathrm{OC}$ cheese and the period from 83 to 140 days where decreases are apparent; variable amounts of $\mathrm{NaCl}$ applied to the fresh cheeses, which may lead to different intrinsic rates of breakdown of proteins by 


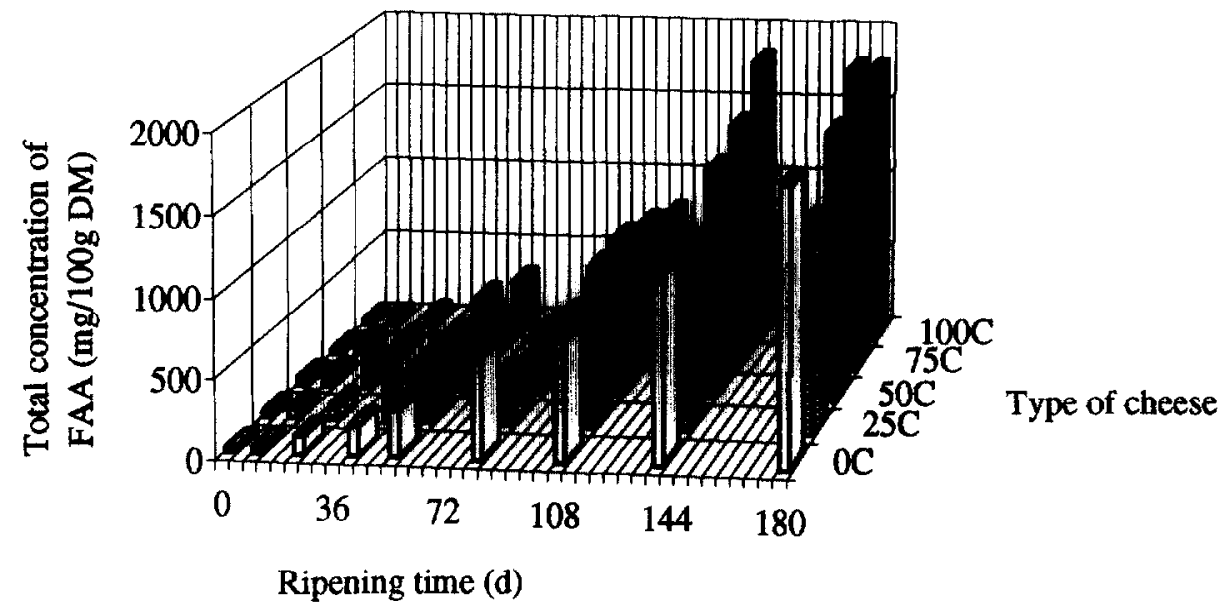

Figure 1 Evolution of concentration of total free amino acids throughout ripening for the various experimental cheeses.

residual rennet (Guinee and Fox, 1993), could (at least partially) be responsible for the aforementioned variability, especially knowing that independent cheeses (rather than the same cheese consecutively) were assayed throughout the ripening period.

The major FAA present in the various experimental cheeses and throughout the ripening period were valine, leucine and phenylalanine; each one represented per se more than $10 \%$ and they accounted (as a whole) for $50,49,57,46$ and $42 \%$ of the total FAA pool at 0 days, and $42,42,43,39$ and $36 \%$ at 180 days for $0 \mathrm{C}, 25 \mathrm{C}, 50 \mathrm{C}, 75 \mathrm{C}$ and $100 \mathrm{C}$ cheeses, respectively. These figures are an indication that the type of cheesemaking milk is an important factor in terms of Picante final characteristics since a higher proportion of ewe's milk in general leads to a higher percentual content of dominating FAA. Valine, leucine and phenylalanine have also been listed as major amino acids in several varieties of small ruminants' cheeses, eg ldiazabal (Barcina et al., 1995), Toscano (Lencioni et al., 1987), Telemea (Buruiana and Farag, 1983) and Manchego ripened in olive oil (Ordonnez and Burgos, 1980). According to Polo et al. (1985), the pattern associated with the FAA concentrations results from enzymatic degradation of peptides, as well as from amino acid interconversion, excretion and degradation by various microorganisms.

With regard to other amino acids which account, on an individual basis, for more than $10 \%$ of the total FA $\Lambda$ content in some (but not all) cheeses, proline was observed in the early stages of ripening. According to Barcina et al. (1995), proline is one of the most abundant amino acids present in $\beta$-casein, although it is preferentially released as a dipeptide rather than as an FAA by the microbial flora in

Table 2 Evolution of mean and standard deviation of free amino acid contents in $O C$ cheeses throughout ripening

\begin{tabular}{|c|c|c|c|c|c|c|c|c|c|}
\hline \multirow{2}{*}{$\begin{array}{l}\text { Amino acid } \\
\text { concentration } \\
\left(\mathrm{mg} / 100 \mathrm{~g}_{\mathrm{DM}}\right)\end{array}$} & \multicolumn{9}{|c|}{ Ripening time (days) } \\
\hline & 0 & 9 & 25 & 40 & 55 & 83 & 110 & 140 & 180 \\
\hline Aspartic acid & $2.84 \pm 0.26$ & $0.67 \pm 0.05$ & $4.95 \pm 1.63$ & $4.37 \pm 1.53$ & $16.55 \pm 1.12$ & $65.98 \pm 4.10$ & $14.80 \pm 0.09$ & $36.12 \pm 1.47$ & $104.43 \pm 15.37$ \\
\hline Glutamic acid & $1.01 \pm 0.04$ & $0.89 \pm 0.11$ & $4.80 \pm 1.20$ & $6.39 \pm 1.48$ & $28.07 \pm 1.55$ & $77.13 \pm 3.68$ & $18.94+1.35$ & $72.96 \pm 2.14$ & $114.57 \pm 21.28$ \\
\hline L-Glutamine & $0.07 \pm 0.02$ & $0.20 \pm 0.08$ & ND & $0.57 \pm 0.19$ & $0.90 \pm 0.03$ & $1.43 \pm 0.01$ & $1.34 \pm 0.04$ & ND & $2.18 \pm 0.27$ \\
\hline Serine & $0.06 \pm 0.03$ & $0.17 \pm 0.132$ & $2.19 \pm 0.81$ & $3.05 \pm 0.67$ & $7.16 \pm 0.11$ & $19.21 \pm 0.89$ & $11.04 \pm 0.36$ & $17.98 \pm 0.07$ & $43.13 \pm 1.88$ \\
\hline Asparagine & $0.08 \pm 0.02$ & $0.10 \pm 0.03$ & $2.39 \pm 0.44$ & $2.97 \pm 0.79$ & $6.29 \pm 0.23$ & $10.64 \pm 0.07$ & $2.80 \pm 0.37$ & $7.62 \pm 0.01$ & $6.83 \pm 2.72$ \\
\hline Glycine & $0.19 \pm 0.01$ & $0.12 \pm 0.01$ & $0.75 \pm 0.03$ & $0.89 \pm 0.04$ & $1.92 \pm 0.03$ & $3.84 \pm 0.09$ & $2.96 \pm 0.05$ & $3.73 \pm 0.08$ & $13.81 \pm 0.24$ \\
\hline Histidinc & $0.66 \pm 0.06$ & $0.52 \perp 0.01$ & $2.72 \pm 0.18$ & $4.94 \pm 0.40$ & $6.69 \pm 0.16$ & $15.26 \pm 0.22$ & $13.96 \pm 1.51$ & $20.42 \pm 0.19$ & $28.36 \pm 0.19$ \\
\hline Taurine & ND & ND & $2.18 \pm 0.12$ & $1.82 \pm 0.01$ & $2.95 \pm 0.13$ & $3.30 \pm 0.06$ & ND & $N \bar{D}$ & $\mathrm{ND}$ \\
\hline $\begin{array}{l}\gamma \text {-Aminobutyric } \\
\text { acid }\end{array}$ & $0.09 \pm 0.02$ & $0.33 \pm 0.01$ & $3.80 \pm 0.07$ & $6.28 \pm 0.43$ & $7.23 \pm 0.46$ & $14.57 \pm 0.26$ & $15.37 \pm 0.47$ & $16.53 \pm 0.14$ & $13.33 \pm 0.46$ \\
\hline Threonine & $0.27 \pm 0.03$ & $0.24 \pm 0.01$ & $1.65 \pm 0.11$ & $2.63 \pm 0.21$ & $4.70+0.26$ & $10.67 \pm 0.15$ & $8.36 \pm 0.47$ & $8.82 \pm 0$ & $25.42 \pm 0.86$ \\
\hline Arginine & $\overline{D D}$ & $\overline{\mathrm{ND}}$ & & & ND & $N \bar{D}$ & ND & $\mathrm{ND}$ & ND \\
\hline Alanine & $0.86 \pm 0.04$ & $1.39 \pm 0.01$ & $7.56 \pm 0.25$ & $11.05 \pm 0.69$ & $15.02 \pm 1.04$ & $22.89 \pm 0.24$ & $34.07 \pm 0.34$ & $65.67 \pm 1.44$ & $83.30 \pm 2.89$ \\
\hline Proline & $3.39 \pm 0.25$ & $6.81 \pm 0.01$ & $11.20 \pm 0.22$ & $6.96 \pm 0.36$ & $8.06 \pm 0.70$ & $11.29 \pm 0.20$ & $12.66 \pm 0.25$ & $22.21 \pm 1.08$ & $64.60 \pm 4.89$ \\
\hline Tyrosine & $1.03 \pm 0.12$ & $1.01 \pm 0.01$ & $2.87 \pm 0.11$ & $5.63 \pm 0.37$ & $5.02 \pm 0.34$ & $14.72 \pm 0.06$ & $23.33 \pm 1.20$ & $31.79 \pm 0.34$ & $64.18 \pm 8.19$ \\
\hline Valine & $5.01 \pm 0.44$ & $5.02 \pm 0.17$ & $14.69 \pm 0.19$ & $28.83 \pm 1.00$ & $48.28 \pm 2.66$ & $105.38 \pm 0.27$ & $181.60 \pm 4.34$ & $251.79 \pm 0.99$ & $324.40 \pm 25.27$ \\
\hline Methionine & $0.90 \pm 0.30$ & $1.29 \pm 0.02$ & $3.61 \pm 0.11$ & $6.68 \pm 0.16$ & $3.95 \pm 0.27$ & $8.90 \pm 0.42$ & $9.20 \pm 0.27$ & $17.80 \pm 0.54$ & $27.68 \pm 1.89$ \\
\hline Cystcine & $0.53 \pm 0.13$ & $0.93 \pm 0.02$ & $1.39 \pm 0.61$ & $0.96 \pm 0.01$ & $1.98 \pm 1.00$ & $5.50 \pm 0.25$ & $5.28 \pm 0.37$ & $2.81 \pm 1.18$ & $3.46 \pm 0.10$ \\
\hline Isoleucine & $0.43 \pm 0.04$ & $1.40 \pm 0.09$ & $5.47 \pm 0.09$ & $12.57 \pm 0.33$ & $23.06 \pm 1.63$ & $53.98 \pm 0.27$ & $89.76 \pm 1.83$ & $121.73 \pm 1.45$ & $173.06 \pm 13.30$ \\
\hline Leucine & $6.69 \pm 0.61$ & $8.20 \pm 0.71$ & $18.36 \pm 0.34$ & $33.03 \pm 0.38$ & $46.54 \pm 3.44$ & $74.45 \pm 0.56$ & $132.54 \pm 2.40$ & $181.48 \pm 1.77$ & $249.40 \pm 22.87$ \\
\hline Phenylalanine & $3.23 \pm 0.33$ & $5.65 \pm 0.20$ & $12.10 \pm 0.13$ & $26.13 \pm 2.63$ & $32.79 \pm 5.74$ & $61.13 \pm 0.22$ & $97.41 \pm 2.45$ & $120.39 \pm 1.44$ & $146.99 \pm 13.15$ \\
\hline Tryptophan & $1.57 \pm 0.14$ & $1.79 \pm 0.07$ & $3.54 \pm 0.57$ & $6.57 \pm 0.91$ & $12.55 \pm 1.80$ & $28.69 \pm 0.91$ & $31.91 \pm 0.76$ & $74.60 \pm 1.24$ & $77.53 \pm 4.90$ \\
\hline Lysine & $0.74 \pm 0.06$ & $1.45 \pm 0.04$ & $5.23 \pm 0.01$ & $11.01 \pm 0.45$ & $13.09 \pm 0.87$ & $31.24 \pm 0.14$ & $44.58+1.60$ & $99.70 \pm 1.49$ & $161.53 \pm 11.50$ \\
\hline
\end{tabular}

ND - not detected; DM - dry matter. 
Table 3 Evolution of mean and standard deviation of free amino acid contents in $25 \mathrm{C}, 50 \mathrm{C}$ and $75 \mathrm{C}$ cheeses throughout ripening

\begin{tabular}{|c|c|c|c|c|c|c|c|c|c|}
\hline \multirow{2}{*}{$\begin{array}{l}\text { Amino acid } \\
\text { concentration } \\
\left(\mathrm{mg} / 100 \mathrm{~g}_{\mathrm{DM}}\right)\end{array}$} & \multicolumn{9}{|c|}{ Ripening time (days) } \\
\hline & 0 & 9 & 25 & 40 & 55 & 83 & 110 & 140 & 180 \\
\hline Aspartic acid & $3.15 \pm 2.27$ & $2.60 \pm 1.40$ & $1.75 \pm 1.19$ & $3.20 \pm 3.04$ & $3.96 \pm 2.32$ & $9.98 \pm 5.05$ & $41.73 \pm 15.48$ & $75.36 \pm 26.10$ & $102.27 \pm 31.04$ \\
\hline Glutamic acid & $1.22 \pm 0.02$ & $2.42 \pm 1.19$ & $2.97 \pm 0.75$ & $4.39 \pm 2.86$ & $6.48 \pm 2.44$ & $13.65 \pm 6.32$ & $43.52 \pm 19.87$ & $97.46 \pm 28.01$ & $108.96 \pm 30.65$ \\
\hline L-Glutamine & $0.09 \pm 0.08$ & $0.40 \pm 0.15$ & $0.49 \pm 0.15$ & $0.73 \pm 0.13$ & $0.31 \pm 0.53$ & $1.02 \pm 0.23$ & $1.80 \pm 0.10$ & $0.61 \pm 1.05$ & $2.15 \pm 0.34$ \\
\hline Serine & $0.23 \pm 0.03$ & $0.67 \pm 0.18$ & $1.48 \pm 0.43$ & $2.32 \pm 0.60$ & $3.15 \pm 1.31$ & $6.31 \pm 2.02$ & $17.97 \pm 7.35$ & $20.29 \pm 3.50$ & $43.33+8.35$ \\
\hline Asparagine & $0.24 \pm 0.03$ & $0.75 \pm 0.35$ & $1.53 \pm 0.43$ & $2.71 \pm 0.61$ & $3.81 \pm 0.86$ & $3.56 \pm 1.32$ & $8.15 \pm 1.68$ & $10.21 \pm 2.67$ & $6.55 \pm 0.45$ \\
\hline Glycine & $0.25 \pm 0.10$ & $0.34 \pm 0.10$ & $0.56 \pm 0.12$ & $0.90 \pm 0.11$ & $1.54 \pm 0.21$ & $2.04 \pm 0.17$ & $3.90 \pm 0.45$ & $6.64 \pm 1.86$ & $15.50 \pm 3.97$ \\
\hline Histidine & $0.35 \pm 0.33$ & $0.83 \pm 0.73$ & $2.72 \pm 0.37$ & $4.73 \pm 1.32$ & $6.59 \pm 1.26$ & $7.13 \pm 1.60$ & $20.34 \pm 4.11$ & $17.14 \pm 1.94$ & $23.00 \pm 2.50$ \\
\hline Taurine & $0.33 \pm 0.38$ & $0.51 \pm 0.72$ & $1.33 \pm 0.55$ & $1.61 \pm 0.18$ & $1.58 \pm 1.41$ & $1.65 \pm 1.43$ & ND & $1.79 \pm 1.56$ & ND \\
\hline $\begin{array}{l}\gamma \text {-Aminobutyric } \\
\text { acid }\end{array}$ & $0.13 \pm 0.06$ & $0.43 \pm 0.30$ & $1.26 \pm 0.74$ & $3.79 \pm 1.06$ & $7.89 \pm 4.08$ & $8.51 \pm 2.55$ & $19.84 \pm 0.25$ & $17.65 \pm 5.75$ & $13.32 \pm 3.99$ \\
\hline Threonine & $0.32 \pm 0.05$ & $0.57 \pm 0.17$ & $1.31 \pm 0.14$ & $2.24 \pm 0.22$ & $3.97 \pm 1.05$ & $5.09 \pm 0.78$ & $12.33 \pm 1.39$ & $16.28 \pm 2.83$ & $26.13 \pm 5.71$ \\
\hline Arginine & ND & ND & $\mathrm{ND}$ & $\mathrm{ND}$ & ND & ND & & & \\
\hline Alanine & $1.16 \pm 0.21$ & $2.38 \pm 0.99$ & $4.84 \pm 1.84$ & $8.60 \pm 1.22$ & $15.62 \pm 3.97$ & $15.02 \pm 1.21$ & $33.36 \pm 1.84$ & $70.56 \pm 22.22$ & $78.57 \pm 19.89$ \\
\hline Proline & $5.55 \pm 1.50$ & $7.44 \pm 0.95$ & $9.56 \pm 6.40$ & $8.43 \pm 1.35$ & $11.47 \pm 1.15$ & $12.07 \pm 1.52$ & $23.29 \pm 5.67$ & $36.93 \pm 9.12$ & $69.21 \pm 18.34$ \\
\hline Tyrosine & $0.82 \pm 0.41$ & $1.46 \pm 0.26$ & $2.36 \pm 0.64$ & $4.17 \pm 1.60$ & $5.63 \pm 2.69$ & $7.73 \pm 0.84$ & $29.84 \pm 6.14$ & $42.05 \pm 4.94$ & $56.18 \pm 11.81$ \\
\hline Valine & $7.96 \pm 3.10$ & $11.61 \pm 2.98$ & $15.04 \pm 1.73$ & $28.82 \pm 9.75$ & $52.25 \pm 11.27$ & $73.07 \pm 11.02$ & $197.34 \pm 12.64$ & $302.09 \pm 67.01$ & $310.49 \pm 56.49$ \\
\hline Methionine & $1.82 \pm 0.46$ & $2.76 \pm 0.82$ & $4.92 \pm 0.66$ & $6.47 \pm 0.69$ & $6.76 \pm 2.43$ & $6.25 \pm 0.73$ & $17.06 \pm 2.31$ & $19.24 \pm 1.88$ & $27.25 \pm 3.85$ \\
\hline Cysteine & $0.65 \pm 0.20$ & $0.75 \pm 0.23$ & $2.14 \pm 1.33$ & $2.85 \pm 0.49$ & $2.79 \pm 1.01$ & $3.42 \pm 0.17$ & $3.66 \pm 1.79$ & $6.39 \pm 1.95$ & $3.20 \pm 0.67$ \\
\hline Isoleucine & $1.69 \pm 0.58$ & $2.58 \pm 0.09$ & $5.48 \pm 0.22$ & $13.24 \pm 2.52$ & $26.76 \pm 2.65$ & $39.98 \pm 5.93$ & $104.09 \pm 12.32$ & $144.09 \pm 21.47$ & $169.23 \pm 26.80$ \\
\hline Leucine & $9.49 \pm 3.12$ & $13.82 \pm 2.59$ & $18.50 \pm 1.78$ & $32.64 \pm 8.86$ & $49.98 \pm 10.02$ & $45.13 \pm 6.61$ & $148.23 \pm 17.02$ & $193.71 \pm 19.63$ & $228.33 \pm 35.81$ \\
\hline Phenylalanine & $5.59 \pm 1.56$ & $9.31 \pm 2.38$ & $14.47 \pm 1.63$ & $24.98 \pm 4.07$ & $40.53 \pm 8.20$ & $43.49 \pm 5.09$ & $111.22 \pm 13.64$ & $129.91 \pm 12.57$ & $146.05 \pm 18.04$ \\
\hline Tryptophan & $2.36 \pm 0.65$ & $3.34 \pm 1.04$ & $4.83 \pm 0.94$ & $4.98 \pm 1.69$ & $11.76 \pm 4.31$ & $12.66 \pm 0.78$ & $40.77 \pm 3.40$ & $82.57 \pm 21.34$ & $79.77 \pm 19.23$ \\
\hline Lysine & $1.20+0.16$ & $2.93 \pm 0.66$ & $6.28 \pm 1.44$ & $10.28 \pm 2.93$ & $16.72 \pm 5.87$ & $18.88 \pm 2.75$ & $62.90 \pm 7.05$ & $113.69 \pm 29.93$ & $151.98 \pm 36.34$ \\
\hline
\end{tabular}

ND - not detected; DM - dry matter.

cheese (Visser, 1977; Smid et al., 1991; Cogan and Hill, 1993); hence, the higher relative proportion of free proline detected at 0 and 9 days is probably related to $\beta$-casein cleavage brought about by plasmin, the native protease of milk, soon after the coagulation step. According to Fresno et al. (1993), proline was the dominant FAA detected in Armada cheese curd; studies on Kaskhawal cheese (Buruiana and Zeidan, 1982) have shown a marked increase of free proline during the first 3 months of ripening and decreases in its relative concentration towards the end of ripening. In the later stages of ripening, isoleucine also appeared among the major FAA in all experimental cheeses, ie isoleucine was detected above the $10 \%$ threshold after 55 days of ripening in $50 \mathrm{C}$ and $75 \mathrm{C}$ cheeses, after 83 days in $25 \mathrm{C}$ cheeses, and after 110 days in $0 \mathrm{C}$ and $100 \mathrm{C}$ cheeses. According to Favier (1987) and Parkash and Jeness (1968), proline, glutamic acid, leucine and isoleucine represent approximately $40 \%$ of the total amino acid residue inventory of caprine casein. By the end of ripening (180 days), valine, leucine and isoleucine

Table 4 Evolution of mean and standard deviation of free amino acid contents in $100 \mathrm{C}$ cheeses throughout ripening

\begin{tabular}{|c|c|c|c|c|c|c|c|c|c|}
\hline \multirow{2}{*}{$\begin{array}{l}\text { Amino acid } \\
\text { concentration } \\
\left(\mathrm{mg} / 100 \mathrm{~g}_{\mathrm{DM}}\right)\end{array}$} & \multicolumn{9}{|c|}{ Ripening time (days) } \\
\hline & 0 & 9 & 25 & 40 & 55 & 83 & 110 & 140 & 180 \\
\hline Aspartic acid & $4.27 \pm 0.25$ & $0.98 \pm 0.26$ & $0.82 \pm 0.61$ & $10.51 \pm 2.11$ & $19.65 \pm 1.32$ & $40.12 \pm 1.53$ & $48.04 \pm 2.57$ & $126.84 \pm 8.61$ & $127.71 \pm 12.85$ \\
\hline Glutamic acid & $1.36 \pm 0.05$ & $1.19 \pm 0.01$ & $2.58 \pm 0.75$ & $11.36 \pm 1.59$ & $20.76 \pm 1.18$ & $47.07 \pm 2.08$ & $39.86 \pm 2.96$ & $163.62 \pm 12.30$ & $140.85 \pm 15.19$ \\
\hline L-Glutamine & $0.19 \pm 0.01$ & $0.40 \pm 0.04$ & $\mathrm{ND}$ & $0.76 \pm 0.03$ & $1.12 \pm 0.11$ & $1.87 \pm 0.09$ & $1.86 \pm 0.23$ & $1.80 \pm 0.01$ & $3.88 \pm 0.04$ \\
\hline Serine & $0.14 \pm 0.01$ & $0.41 \pm 0.02$ & $0.42 \pm 0.21$ & $3.85 \pm 0.30$ & $6.49 \pm 0.14$ & $14.66 \pm 1.14$ & $15.42 \pm 1.82$ & $25.42 \pm 0.24$ & $49.07 \pm 1.27$ \\
\hline Glycine & $0.14 \pm 0.01$ & $0.29 \pm 0.01$ & $0.68 \pm 0.18$ & $1.09 \pm 0.05$ & $1.81 \pm 0.02$ & $3.57 \pm 0.07$ & $3.45 \pm 0.25$ & $13.16 \pm 0.34$ & $19.64 \pm 0.67$ \\
\hline Histidine & $0.46 \pm 0.01$ & $0.68 \pm 0.03$ & $1.37 \pm 0.15$ & $4.09 \pm 0.10$ & $6.34 \pm 0.07$ & $9.16 \pm 0.32$ & $16.28 \pm 1.66$ & $23.50 \pm 0.43$ & $31.23 \pm 1.46$ \\
\hline Taurine & $0.75 \pm 0.01$ & $1.06 \pm 0.01$ & $1.46 \pm 0.13$ & $2.41 \pm 0.06$ & $2.71 \pm 0.05$ & $3.73 \pm 0.10$ & ND & $2.34 \pm 0.01$ & $2.99 \pm 0.01$ \\
\hline $\begin{array}{l}\gamma-\text { Aminobutyric } \\
\text { acid }\end{array}$ & $0.19 \pm 0.01$ & $0.20 \pm 0.02$ & $0.61+0.18$ & $5.09 \pm 0.02$ & $6.15 \pm 0.12$ & $7.19 \pm 0.39$ & $12.62 \pm 0.99$ & $20.49 \pm 0.74$ & $17.49 \pm 0.17$ \\
\hline Threonine & $0.27 \pm 0.01$ & $0.44 \pm 0.03$ & $0.83 \pm 0.01$ & $2.49 \pm 0.06$ & $4.68 \pm 0.04$ & $8.88 \pm 0.39$ & $10.42 \pm 0.93$ & $22.99 \pm 0.34$ & $34.30 \pm 0.42$ \\
\hline Arginine & & & & & & & & & \\
\hline Alanine & $1.24 \pm 0.03$ & $1.45 \pm 0.02$ & $2.75 \pm 0.02$ & $12.15 \pm 0.09$ & $12.06 \pm 0.07$ & $16.50 \pm 1.10$ & $29.15 \pm 2.35$ & $94.74 \pm 5.39$ & $106.67 \pm 0.63$ \\
\hline Valine & $4.38 \pm 0.04$ & $4.86 \pm 0.21$ & $8.30 \pm 0.07$ & $28.66 \pm 1.57$ & $53.99 \pm 1.93$ & $75.62 \pm 8.30$ & $179.19 \pm 13.23$ & $352.20 \pm 16.49$ & $309.22 \pm 8.65$ \\
\hline Methionine & $0.72 \pm 0.01$ & $1.12 \pm 0.06$ & $2.33 \pm 0.07$ & $5.18 \pm 0.20$ & $5.45 \pm 0.30$ & $5.68 \pm 0.62$ & $11.28 \pm 1.20$ & $24.91 \pm 0.98$ & $26.38 \pm 0.85$ \\
\hline Cysteine & $0.16 \pm 0.01$ & $0.40 \pm 0.10$ & $0.84 \pm 0.34$ & $1.84 \pm 0.72$ & $3.56 \pm 0.86$ & $3.00 \pm 0.16$ & $3.96 \pm 0.76$ & $5.24 \pm 0.90$ & $3.55 \pm 0.41$ \\
\hline Isoleucine & $0.76 \pm 0.02$ & $1.29 \pm 0.12$ & $3.92 \pm 0.10$ & $15.45 \pm 0.28$ & $28.43 \pm 0.09$ & $36.90 \pm 2.85$ & $84.99 \pm 3.84$ & $170.00 \pm 8.06$ & $154.45 \pm 4.46$ \\
\hline Leucine & $6.33 \pm 0.28$ & $6.80 \pm 0.40$ & $12.14 \pm 0.24$ & $30.51 \pm 1.36$ & $47.87 \pm 0.57$ & $41.82 \pm 3.83$ & $106.60 \pm 3.29$ & $226.00 \pm 11.60$ & $198.83 \pm 9.71$ \\
\hline Phenylalanine & $4.06 \pm 0.06$ & $5.12 \pm 0.30$ & $11.33 \pm 0.30$ & $29.12 \pm 3.45$ & $42.52 \pm 3.68$ & $44.69 \pm 6.69$ & $86.64 \pm 7.20$ & $155.36 \pm 8.39$ & $135.37 \pm 3.21$ \\
\hline Tryptophan & $2.25 \pm 0.19$ & $2.18 \pm 0.16$ & $4.22 \pm 0.20$ & $8.71 \pm 0.16$ & $14.93 \pm 1.77$ & $19.39 \pm 2.57$ & $37.62 \pm 3.11$ & $108.16 \pm 4.32$ & $101.28 \pm 1.62$ \\
\hline Lysine & $1.21 \pm 0.07$ & $1.41 \pm 0.08$ & $4.23 \pm 0.02$ & $8.03 \pm 0.11$ & $12.09 \pm 0.18$ & $20.30 \pm 1.84$ & $51.24 \pm 3.73$ & $165.29 \pm 8.92$ & $195.27 \pm 3.51$ \\
\hline
\end{tabular}

ND - not detected; DM - dry matter. 
were the major FAA in $0 \mathrm{C}, 50 \mathrm{C}$ and $75 \mathrm{C}$ cheeses, where they represented 43,45 and $41 \%$ of the total FAA content; in $25 \mathrm{C}$ cheeses, phenylalanine is also included in this group and altogether they accounted for $53 \%$; in $100 \mathrm{C}$ cheeses, valine, leucine and lysine were the major FAA, and they represented $39 \%$ as a whole. Following inspection of the ANOVA, the ratio of mixture of goat's and ewe's milks and, to a greater extent, the ripening time have statistically significant effects on the content of free valine, leucine, phenylalanine and lysine; for isoleucine, the former factor was not significant at the $5 \%$ level. Scheffés $F$ multiple comparison test revealed that the evolution of concentration of isoleucine between 0 and 9 days, between 40 and 83 days, and between 110 and 180 days was not significant at the $5 \%$ level, nor was the evolution of leucine between 55 and 83 days or the evolution of valine and phenylalanine between 140 and 180 days. Scheffé's $F$ test revealed also that, depending on the FAA in question, several increments in the percent composition of goat's milk in the cheesemilk were not statistically significant; eg the $0 \mathrm{C}$ and $25 \mathrm{C}$ cheeses did not exhibit significant differences in terms of contents of leucine and phenylalanine, whereas the $25 \mathrm{C}$ and $75 \mathrm{C}$ cheeses did not exhibit significant differences in terms of contents of valine, leucine and lysine.

The relative proportions of histidine, tyrosine, tryptophan and lysine were in general constant throughout the ripening period for the various experimental cheeses. Their relative proportion was between $c a .2$ and $5 \%$ of the total FAA content for histidine and tyrosine, and between $c a .5$ and $10 \%$ for tryptophan and lysine. The presence of tryptophan contrasts with data reported by González de Llano et al. (1991), who did not detect tryptophan in any of the samples analyzed. Aspartic acid was present in our experimental cheeses at relative proportions that were extremely variable, attaining values from below $2 \%$ of the total FAA concentration for the $50 \mathrm{C}, 75 \mathrm{C}$ and $100 \mathrm{C}$ cheeses between 25 and 55 days, to above $10 \%$ for the $0 \mathrm{C}$ cheeses between 55 and 83 days and for the $25 \mathrm{C}$ and $100 \mathrm{C}$ cheeses at 0 days. Inspection of the ANOVA indicated that ripening time and, to a lesser degree, the ratio of mixture of goat's and ewe's milks were significant factors at the $5 \%$ level of significance with regard to free histidine, tyrosine, tryptophan and aspartic acid concentrations. No significant differences were revealed by Scheffé's $F$ test for the concentration of aspartic acid between 0 and 40 days, for the concentration of histidine between 110 and 140 days, and for the concentration of tryptophan between 140 and 180 days. In terms of influence of volumetric ratios of goat's and ewe's milks, Scheffé's $F$ test indicated that an increment of $25 \%$ of goat's milk in the preparation of cheesemaking milk was not significant for the concentrations of histidine, tyrosine, tryptophan and aspartic acid, whereas an increment of $50 \%$ was not significant for the concentrations of histidine and tyrosine. Cheese manufactured with $100 \%$ goat's milk or $100 \%$ ewe's milk did not display statistical differences in terms of tyrosine and tryptophan contents.

In Picante cheese, the relative proportion of glutamic acid increased throughout the ripening period and reached values of $6.6,6.8,5.4,7.4$ and $7.9 \%$ of the total FAA content by 180 days of ripening in the $0 \mathrm{C}, 25 \mathrm{C}, 50 \mathrm{C}, 75 \mathrm{C}$ and $100 \mathrm{C}$ cheeses, respectively. Glutamic acid is found in small amounts in Manchego cheese after long ripening periods (Ordonez and Burgos, 1980). Although the ratio of mixing of goat's and ewe's milks and the ripening time were found to be statistically significant factors overall, Scheffé's $F$ test indicated no significant differences between 0 and 9 days and between 140 and 180 days for the concentration of this amino acid. The $25 \%$ volumetric increment of goat's milk did not lead to statistically significant differences between the 0C and $25 \mathrm{C}$ cheeses, and between the $25 \mathrm{C}$ and $50 \mathrm{C}$ cheeses.

$\gamma$-Aminobutyric acid, present in low-quality cheeses (Choisy et al., 1990), was found in small concentrations in Picante. Despite the fact that its concentration increased continuously throughout the ripening period, its higher relative proportion (between $c a .2$ and $5 \%$ of the total FAA content) was detected in intermediate stages of the ripening period for all experimental cheeses. In the beginning and by the end of the maturation period, the $\gamma$-aminobutyric acid contents represented less than $2 \%$ of the total FAA content. Scheffé's $F$ test indicated no significant differences between 110 and 140 days in terms of the concentration of this FAA.

The less abundant FAA (ie those whose content was always less than $2 \%$ of the total FAA content in all experimental cheeses) were glutamine and glycine. Serine, asparagine, taurine and threonine were also below the aforementioned threshold in most cheeses. The low concentrations of taurine contrast with reports by Mehaia and Al-Kanhal (1992), who claimed that taurine is the most abundant FAA in goat's milk; however, very low concentrations of taurine (approximately $0.26 \%$ of the total FAA content) were also reported by Barcina et al. (1995) in Idiazabal cheese by 360 days of ripening. Arginine, which has been reported to be responsible for an unpleasant bitter-sweet taste (Lemieux and Simard, 1992), could not be detected by the analytical technique utilized. Sala-Trepat and Burgos (1972) reported the absence of arginine in some samples of Cabrales cheese.

Linear regression analysis applied to the contents of the main FAA in our experimental Picante cheeses showed that good correlations exist between their content and ripening time; eg the correlation coefficients between the contents of valine, isoleucine, leucine and phenylalanine, and ripening time where positive and higher than 0.93 . This is in agreement with regression analyses applicd to the amino acid nitrogen contents assayed by two spectrophotometric 
methods (ie using either 2,4,6-trinitrobenzenesulfonic acid or cadmium-ninhydrin), in which case the correlation coefficients were all above 0.89 (Freitas et al., 1997).

\section{CONCLUSIONS}

As expected, the total concentration of FAA increased with ripening time for every proportion of ewe's and goat's milks, and ripening time actually exhibited a stronger effect than said proportion. However, significant differences could be detected in terms of amino acid profile when the proportion of ewe's and goat's milks were changed (eg valine changed from $251 \pm 0.99$ to $352.20 \pm 16.49 \mathrm{mg} / 100$ $\mathrm{g}_{\mathrm{DM}}$, isoleucine from $121.73 \pm 1.45$ to $170.00 \pm 8.06$ $\mathrm{mg} / 100 \mathrm{~g}_{\mathrm{DM}}$, leucine from $181.48 \pm 1.77$ to $226.00 \pm$ $11.60 \mathrm{mg} / 100 \mathrm{~g}_{\mathrm{DM}}$, phenylalanine from $120.39 \pm 1.44$ to $155.36 \pm 8.39 \mathrm{mg} / 100 \mathrm{~g}_{\mathrm{DM}}$, and lysine from $99.70 \pm 1.49$ to $165.29 \pm 8.92 \mathrm{mg} / 100 \mathrm{~g}_{\mathrm{DM}}$ in 140-day ripened cheeses when plain ewe's milk was substituted by plain goat's milk). Therefore, standardization of Picante cheese will not be possible unless such milk proportions are constrained to a tight range, especially knowing that some FAA detected play a role in terms of taste.

\section{ACKNOWLEDGFMENTS}

The authors are grateful to the members of the technical board of the Governmental Directorate of Agriculture of the Region of Beira Interior (DRABI, Portugal) for their cooperation in supervising the local manufacture of cheeses according to the design presented and in transporting such cheeses to the ESB premises. Financial support for author A. C. F. was provided by a Ph.D. fellowship within the Programme for the Creation of National Infrastructures in Applied Science and Investigation (CIENCIA) administered by the National Board for Scientific and Technological Investigation (JNICT, Portugal). Partial financial support for the research expenses was provided by project 'PROTOLACTIS: produção, por tecnologias optimizadas, de lacticínios tradicionais', administered by PAMAF (INIA, Portugal).

\section{REFERENCES}

Alonso, M. L., Alvarez, A. I. and Zapico, J. (1994) Rapid analysis of free amino acids in infant foods. Joumal of Liquid Chromatography 17, 4019-4030

Aston, J. W. and Dulley, J. R. (1982) Cheddar cheese flavour. Australian Journal of Dainy Technology 37, 59-64

Barcina, Y., Ibáñez, F. C. and Ordónez, A. I. (1995) Evolution of free amino acids during Idiazábal cheese ripening. Food Control 6, 161-164
Buruiana, L. M. and Farag, S. I. (1983) The variation of amino acids in Tclemca checse during pickling. Egyptian Journal of Dainy Science 11, 53-59

Buruiana, L. M. and Zeidan, A. A. (1982) Variation of free amino acids in Kashkawal Dalia cheese during ripening. Egyptian Journal of Dairy Science 10, 209--213

Choisy, C., Desmazeaud, M., Gripon, J. C., Lamberet, G., Lenoir, J. and Tourneur, C. (1990) El Queso, Omega, S. A. (ed.). André Eck, Barcelona, pp. 57-91

Cogan, T. M. and Hill, C. (1993) Cheese: Chemistry, Physics and Microbiology, P. F. Fox (ed.). Chapman \& Hall, London, pp. 193-255

Cruz, A. A. (1945) Lacticínios da Beira Baixa: Queijo à ovelheira e queijo à cabreira. Boletim Pecuário (Lisboa) 12, 55-100

Favier, J. C. (1987) Composition des fromages de chèvrc. Cahiers de Nutrition et Diétetique 22, 117-123

Furtado, M. M. and Partridge, J. A. (1988) Characterization of nitrogen fractions during ripening of a soft cheese made from ultrafiltration retentates. Journal of Dairy Science 71, $2877-2884$

Freitas, A. C., Fresno, J. B., Prieto, B., Malcata, F. X. and Carballo, F. J. (1997) Effects of ripening time and combination of ovine and caprine milks on proteolysis of Picante cheese. Food Chemistry 2, 219-229

Freitas, A. C. and Malcata, F. X. (1996) Influence of milk type, coagulant, salting procedure and ripening time on the final characteristics of Picante cheese. International Dainy Joumal 6, $1099-1116$

Freitas, A. C., Pais, C., Malcata, F. X. and Hogg, T. A. (1996) Microbiological characterization of Picante da Beira Baixa cheese. Journal of Food Protection 59, 155-160

Freitas, A. C., Sousa, M. and Malcata, F. X. (1995) Effect of ripening time and the combination of ewe and goat milk on the microflora of Picante cheese. Italian Journal of Food Science 7, $361-377$

Fresno, J. M., Carballo, J., Bernardo, A. and González, J. (1993) Evolucion de los aminoacidos libres durante la maduracion del queso de Armada (variedad Sobado). Proc. IX Congreso Nacional de Química (Química Agrícola y Alimentaria), Sevilla, Spain, Vol. 3, pp. 227-232

González de Llano, D., Polo, M. C., Ramos, M. and MartínAlvarez, P. (1991) Free and total amino acids in the non-protein fraction of an artisan blue cheese during ripening. Zeitachnifi fin Lebensmittee-Untersuchung und Forschung 193, $529-5.32$

González de Llano, D., Ramos, M. and Martín-Alvarez, P. J. (1993) Comparative study of different methods for evaluating proteolysis in blue cheese. Zeitachnifi fin Lebensmittee-Untersuchung und Forschung 196, 29-31

Gonzálcz de Llano, D., Ramos, M., Rodríguez, A., Montilla, A. and Juarez, M. (1992) Microbiological and physiocochemical characteristics of Gamonedo Blue cheese during ripening. International Dairy Journal 2, 121-135

Guinee, T. P. and Fox, P. F. (1993). Salt in cheese: physical, chemical and biological aspects. In: Cheese: Chemistry, Physics and Microbiology, P. F. Fox (ed.). Chapman \& Hall, London, pp. 257-302

Lemieux, L. and Simard, R. E. (1992) Bitter flavour in dairy products. II. A review of bitter peptides from caseins: their formation, isolation and identification, structure masking and inhibition. Le Lait 72, 335-382

Lencioni, L., Pisanaelli, A. M., Baldi, E., Fiorentini, R. and Galoppini, C. (1987) Sheep milk cheese made with the addition of alfalfa leaf protein concentrate: proteolysis during ripening. Lebensmittel wissenschaft und Technologie 20, 277-281

Marcos, A. and Mora, M. T. (1982) Proteolysis in Manchego cheese. Evolution of free amino acids. Archiros de Zootecnia 31, 115-129 
McGugan, W. A., Emmons, D. B. and Larmond, E. (1979) Influence of volatile and nonvolatile fractions on intensity of Cheddar cheese flavor. Journal of Dairy Science 62, 398-403

Mehaia, M. A. and Al-Kanhal, M. A. (1992) Taurine and other free amino acids in milk of camel, goat, cow and man. Milchwissenschaft 47, 351-353

Ordónez, J. A. and Burgos, J. (1980) Free amino acids of Manchego cheese ripened in olive oil. Milchwissenschaft 35 , 69-71

Parkash, S. and Jeness, R. (1968) The composition and characteristics of goat's milk: a review. Dairy Science Abstracts 30, 67-87

Polo, C., Ramos, M. and Sánchez, R. (1985) Free amino acids by high performance liquid chromatography and peptides by gel electrophoresis in Mahón cheese during ripening. Food Chemistry 16, 85-96

Ramos, M., Cáceres, I., Polo, C., Alonso, L. and Juárcz, M. (1987) Effect of freezing on soluble nitrogen fraction of Cabrales cheese. Food Chemistry 24, 271-278

Rank, T. C., Grappin, R. and Olson, N. F. (1985) Secondary proteolysis of cheese during ripening: a review. Journal of Dairy Science $68,801-805$
Sala-Trepat, F. J. and Burgos, J. (1972) Maduracion del queso Cabrales: evolución de los aminoacidos libres durante la maduración. Anales de Bromatolgie 24, 61-82

Schmidt, J. L. and Lenoir, J. (1972) Enterococci and their technological capacities. Le Lait 52, 536-557

Smid, E. J., Poolman, B. and Konings, W. N. (1991) Casein utilization by lactococci. Applied and Environmental Microbiology 57, $2447-2452$

Stojslavljevic, T., Rasic, J. and Curcic, R. (1971) A study on the amino acids of yoghurt. I. Amino acids content and biological value of the proteins of different kinds of milk. Milchwissenschaft 26, 147-151

Visser, F. M. W. (1977) Contribution of enzymes from rennet, starter bacteria and milk to proteolysis and flavour development in Gouda cheese. 3. Protein breakdown: analysis of the soluble nitrogen and amino acid nitrogen fraction. Netherlands Milk and Dainy Joumal 31, 210-239

Wallace, D. L. and Harmon, L. G. (1970) Intracellular protease from Streptococcus durans. Journal of Dairy Science 53, 394-402 